\title{
Author Correction: Internalization and vacuolar targeting of the brassinosteroid hormone receptor BRI1 are regulated by ubiquitination
}

Sara Martins, Esther M. N. Dohmann, Anne Cayrel, Alexander Johnson, Wolfgang Fischer, Florence Pojer, Béatrice Satiat-Jeunemaître, Yvon Jaillais, Joanne Chory, Niko Geldner \& Grégory Vert

Correction to: Nature Communications https://doi.org/10.1038/ncomms7151, published online 21 January 2015.

This article contains an error in Supplementary Fig. 2b. The gel image in the lower panel labelled as ACT2 was duplicated from a previous gel image labelled as $U b q 10$ in Figure S5 of a prior publication ${ }^{1}$. The RT-PCR experiment in question has since been repeated to analyze ACTIN2 and BRI1m-CITRINE expression in the WT, bri1/BRI1-mCitrine, bri1/BRI1-mCitrine-Ub and bri1/BRI1-mCitrine$\mathrm{Ub}_{\text {I44A }}$ genotypes described in the original article. 27 cycles of PCR amplification was performed using primers $5^{\prime}$-GCCCA GAAGTCTTGTTCCAG-3 $3^{\prime}$ and $5^{\prime}$-TCATACTCGGCCTTGGAGAT-3 ${ }^{\prime}$ for ACTIN2 and $5^{\prime}$-GACTTCTTCAAGTCCGCCATG-3' and $5^{\prime}$-GTCCTCCTTGAAGTCGATGC-3' for $m$ CITRINE. cDNA was prepared as described in the original article, and PCR products were ran on $2 \%$ and $4 \%$ agarose gels for ACTIN2 and BRI1-mCitrine, respectively. The result of the new experiment appears below as Fig. 1.

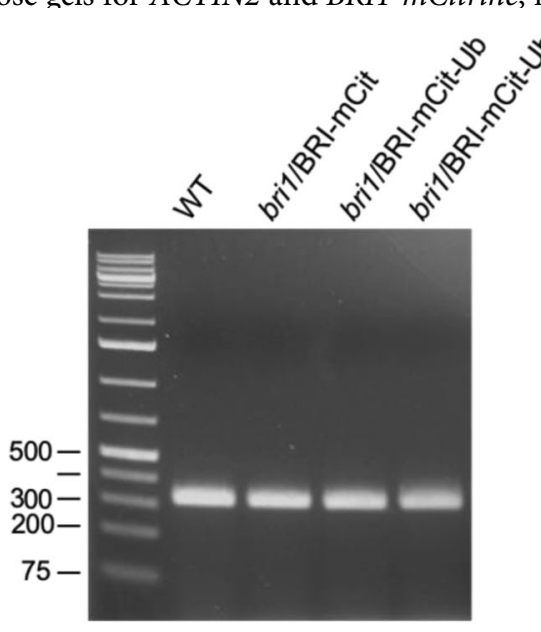

ACTIN2

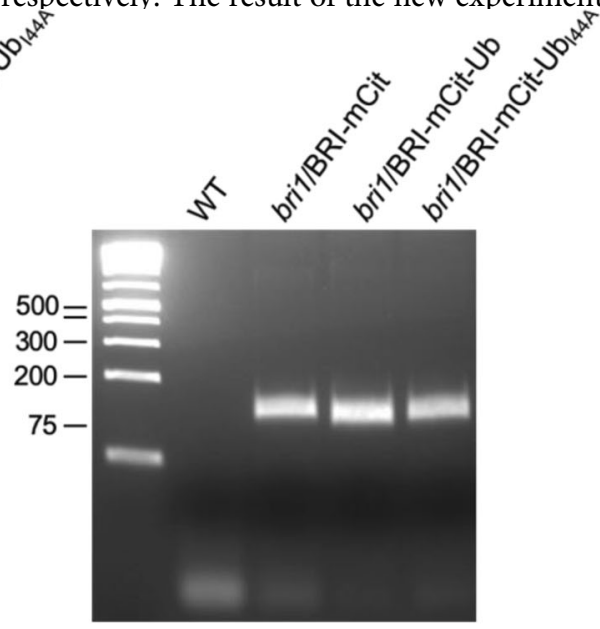

BRI1-mCITRINE

Published online: 17 May 2021

\section{Reference}

1. Vert, G. \& Chory, J. Downstream nuclear events in brassinosteroid signalling. Nature 441, 96-100 (2006). 
(c) Open Access This article is licensed under a Creative Commons Attribution 4.0 International License, which permits use, sharing, adaptation, distribution and reproduction in any medium or format, as long as you give appropriate credit to the original author(s) and the source, provide a link to the Creative Commons license, and indicate if changes were made. The images or other third party material in this article are included in the article's Creative Commons license, unless indicated otherwise in a credit line to the material. If material is not included in the article's Creative Commons license and your intended use is not permitted by statutory regulation or exceeds the permitted use, you will need to obtain permission directly from the copyright holder. To view a copy of this license, visit http://creativecommons.org/licenses/by/4.0/.

(C) The Author(s) 2021 